\title{
BUDAYA ORGANISASI DALAM MENINGKATKAN PRESTASI KERJA PEGAWAI \\ DI BALAI DIKLAT APARATUR SUKAMANDI KEMENTERIAN KELAUTAN DAN PERIKANAN
}

\author{
Asep Djaenudin \\ Balai Diklat Aparatur Kementerian Kelautan dan Perikanan \\ Jl. Raya 2 Sukamandi, Ciasem 41256, Subang-Jawa Barat \\ Email: djaenudin1972@gmail.com
}

\begin{abstract}
The objective of this research is to understand the organizations culture in improving the performance of employees in Balai Diklat Aparatur Sukamandi. Research was conducted using descriptive methods. Research data collected using a questionnaire completed by 30 employees. Research data analyzed using descriptive technical analysis.

Based on the analysis of data obtained the following conclusions: First, perfoemance of employees in Balai Diklat Aparatur Sukamandi relatively good level reached 81.86\%. This is shown by how the employees in performing work in a timely manner, have a responsibility in the work, the results show quality of work achieved, to obey the rules, and foster cooperation. Second: organizations culture in Balai Diklat Aparatur Sukamandi relatively low levels reached only $62.98 \%$. This is indicated by the values and norms about the structure of the task, the applicable regulations, the interaction between employees, and appreciation of the achievements that have not been agreed upon in their entirety as a reference in conducting activities to achieve organizational goals, so that should be improved. Third: organizations culture can potentially lead to increase in employee job performance. Agreement on values and norms will encourage the employee organization in conducting the work in accordance with the objectives of the organization. This is indicated particularly by the structure of tasks that employees can demonstrate the quality of the work.
\end{abstract}

\section{PENDAHULUAN}

Sumber daya manusia pada umumnya merupakan tenaga kerja dan pada khususnya adalah karyawan, maka kehadiran karyawan merupakan faktor yang sangat esensial, yang selalu berperan aktif dan dominan dalam setiap kegiatan kantor dan juga sebagai perencana, pelaku dan penentu dalam terwujudnya tujuan departemen. Sedangkan untuk mengatur karyawan adalah hal yang sulit dan kompleks, karena mereka memiliki pikiran, perasaan, status, keinginan, kebutuhan yang berbeda-beda yang dibawa ke dalam instansi. Manajemen harus mampu menciptakan kondisi kerja yang sangat menguntungkan, sehingga pegawai akan dengan sukarela melaksanakan kewajibannya dengan sebaik-baiknya. Sehingga mereka melihat bahwa pelaksanaan tugas ini memberi makna kepada diri mereka.

Upaya organisasi mencapai tujuan yang diinginkan oleh anggota selalu mengalami kendala, baik yang berasal dari dalam organisasi maupun dari luar organisasi sebagai akibat adanya pengaruh lingkungan di sekitar organisasi. Tantangan organisasi dapat dibagi menjadi dua bagian yaitu: tantangan internal dan eksternal. Tantangan internal berupa perubahan 
karyawan dan perubahan pengembangan, sedangkan tantangan eksternal berupa perubahan ekonomi, perubahan kebijaksanaan, maupun ketatnya persaingan. Tantangan ini tentu saja dapat mempersulit tercapainya proses tujuan organisasi. Sukses tidaknya pengelolaan organisasi tergantung pada keadaan sumber daya manusia. Dengan demikian pengembangan sumber daya manusia dalam suatu organisasi mutlak diperlukan. Sebab tanpa sumber daya manusia yang berkualitas, tujuan organisasi akan sulit terwujud.

Salah satu faktor penentu untuk memperlancar penyelesaian tugas-tugas yang dibebankan kepada pegawai dalam suatu organisasi adalah budaya organisasi. Pola budaya organisasi yang diterapkan di Balai Diklat Aparatur Sukamandi juga membawa pengaruh kepada cara kerja pegawai dalam menjalankan tugas-tugas yang dibebankan kepadanya. Untuk itu perlu adanya suatu kontribusi yang dapat memberikan manfaat bagi organisasi.

\section{METODE PENELITIAN}

Penelitian ini dilaksanakan menggunakan metode deskripitif, yakni metode yang diterapkan untuk mengkaji masalah dengan menggambarkan situasi atau kejadian-kejadian. Penelitian ini tidak dimaksudkan untuk menguji hipotesis, tetapi menggambarkan keseluruhan proses yang terkait dengan masalah penelitian. Penelitian dilaksanakan untuk menggambarkan secara sistematis fakta dan karakteristik data dengan memusatkan

\section{KERANGKA TEORI}

\section{Prestasi Kerja}

Scott A. Snell dan Kenneth N. Wexley dalam Timpe (1993) menjelaskan bahwa prestasi kerja adalah kulminasi dari tiga elemen yang saling berkaitan yaitu keterampilan, upaya, dan sifat keadaankeadaan eksternal. Keterampilan merupakan bahan mentah yang dibawa pegawai ke tempat kerja yang meliputi pengetahuan, kemampuan, kecakapan interpersonal dan kecakapan teknis. Upaya
Memanusiakan pegawai dapat dilakukan oleh instansi sebagai suatu organisasi atau oleh pimpinan. Sikap untuk tidak merendahkan bawahan bahkan sikap menghargai bawahan sebagai manusia perlu ditanamkan. Menghargai bawahan berarti menganggap mereka berkedudukan sama, walaupun secara organisasi kebetulan berkedudukan lebih rendah. Dengan demikian, setiap pemimpin harus belajar menghargai anak buah.

Banyak hal yang dapat menyebabkan terjadinya peningkatan produktivitas kerja seorang pegawai dalam suatu organisasi antara lain: lingkungan kerja; promosi jabatan; pendapatan tiap bulan; minat; sikap; pengetahuan; perhatian pimpinan; tanggung jawab; kesempatan memperoleh pendidikan yang lebih tinggi; kepuasan kerja; budaya organisasi; motivasi berprestasi; kepemimpinan atasan dan lain sebagainya. Namun yang menjadi sasaran utama dalam penelitian ini adalah budaya organisasi dan prestasi kerja.

perhatian pada masalah-masalah yang ada pada saat penelitian berlangsung.

Pelaksanaan penelitian dilakukan melalui tiga tahap yaitu: Tahap orientasi yang merupakan tahap awal memasuki lapangan untuk penjajagan. Tahap pengumpulan dan analisis data yang diarahkan untuk mendapatkan data dalam menjawab masalah penelitian. Tahap Penarikan kesimpulan sebagai jawaban atas masalah penelitian yang diajukan.

digambarkan sebagai motivasi yang diperlihatkan pegawai untuk menyelesaikan pekerjaan. Tingkat upaya berkaitan dengan apa yang akan dilakukan pegawai dalam melaksanakan pekerjaan. Kondisi eksternal merupakan kondisi yang berada di luar kendali pegawai misalnya peralatan kerja yang disediakan olah organisasi dan suasana kerja atau organisasi. 
Adrew E. Sikula dalam Mangkunegara (2000) menjelaskan bahwa penilaian prestasi kerja adalah evaluasi yang sistematis dari pekerjaan pegawai dan potensi yang dapat dikembangkan. Penilaian prestasi kerja dapat digunakan untuk menentukan apakah seorang pegawai

\section{Budaya Organisasi}

Kata budaya (culture) mempunyai banyak arti, budaya setiap orang berbeda dengan orang lain dan budaya akan sulit dijelaskan secara konseptual dan definitif apabila diterapkan dalam organisasi. Dengan demikian organisasi mencakup juga aspek-aspek budaya yang terwujud dalam bentuk cerita-cerita, legenda bisnis yang berhasil, nilai-nilai, simbol-simbol yang bermakna bagi setiap insan yang ada dalam organisasi.

Menurut Kotter dan Hasket (1992) variabel penting yang mempengaruhi kemajuan dan produktivitas organisasi dan perusahaan, bukan pada faktor manajemen, fungsi-fungsi penyelesaian tugas atau struktur organisasi, tetapi adalah pada aspek kultural. Walaupun pada umumnya orangorang di dalam sebuah organisasi menyetujui bahwa organisasi mereka mempunyai budaya dan budaya organisasi atau budaya perusahaan itu sangat penting, tetapi biasanya mereka akan menghadapi kesulitan kalu diminta untuk mendefinisikan secara abstrak.

Hal senada sesuai dengan analisis Robbins (1999) yaitu karakteristik utama yang menjadi pembeda budaya organisasi adalah: (1) inisiatif individual, (2) toleransi terhadap tindakan beresiko, (3) arah, (4) integrasi, (5) dukungan dari manajemen, (6) kontrol, (7) identitas, (8) sistem imbalan, (9) toleransi terhadap konflik, dan (10) pola-pola komunikasi.

Lebih lanjut dapat dijelaskan bahwa: (1) inisiatif individual meliputi

\section{HASIL DAN PEMBAHASAN}

\section{Deskripsi Data}

Melalui penelitian ini telah dikumpulkan data berupa skor variabel prestasi kerja pegawai dan skor budaya organisasi. Data tersebut diperoleh telah melakukan pekerjaanya sesuai dengan tujuan yang ditetapkan. Pada sisi lain penilaian prestasi kerja dapat digunakan untuk menentukan apakah seorang pegawai memiliki potensi yang dapat dikembangkan untuk memperbaiki cara dan hasil pekerjaannya.

tingkat tanggung jawab, kebebasan dan independensi yang mempunyai individu, (2) toleransi terhadap tindakan beresiko meliputi sejauh mana para pegawai dianjurkan untuk bertindak agresif, inovatif dan mengambil resiko, (3) arah, didalamnya termasuk sejauh mana organisasi dapat menetapkan dengan jelas sasaran dan harapan mengenai prestasi, (4) integrasi di dalmnya termasuk sejauh mana unit-unit data oraganisasi didorong untuk bekerja secara terkoordinasi, (5) dukungan dari manajemen meliputi sejauh mana para manajer dapat berkomunikasi dengan jelas dan memberi bantuan serta dukungan terhadap bawahan, (6) kontrol di dalamnya termasuk seperangkat peraturan dan sistem pengawasan dan pengendalian terhadap perilaku pegawai, (7) identitas meliputi sejauh mana para pegawai mengidentifikasikan dirinya secara keseluruhan dengan organisasinya dibandingkan kelompok kerja tertentu atau dengan bidang keahlian professional, (8) sistem imbalan meliputi sejauh mana alokasi imbalan (misalkan kenaikan gaji, dan atau promosi) didasarkan atas kriteria prestasi pegawai sebagai kebalikan dari senioritas, sikap pilih kasih dan sebagainya, (9) toleransi terhadap konflik di dalamnya termasuk sejauh mana para pegawai didorong untuk mengemukakan konflik dan kritik secara terbuka, (10) pola-pola komunikasi di dalamnya termasuk sejauh mana komunikasi organisasi dibatasi oleh hirarki kewenangan formal.

berdasarkan hasil pengisian kuesioner yang dilakukan oleh 30 orang pegawai di Balai Diklat Aparatur Sukamandi. Uraian beriku ini akan mengungkapkan deskripsi data 
masing-masing variabel yang telah dianalisis menggunakan teknik statistik deskriptif meliputi skor minimum, skor

\section{Data Variabel Prestasi kerja pegawai}

Variabel prestasi kerja pegawai dalam penelitian ini telah diukur menggunakan instrumen dalam bentuk kuesioner yang terdiri dari 22 butir pernyataan. Hasil pengukuran untuk setiap butir peryataan ditetapkan dengan memberikan skor minimal 1 dan skor maksimal 4 dari setiap alternatif respon/jawaban yang dipilih oleh responden. Dengan demikian, secara teoretis skor variabel prestasi kerja pegawai Balai Diklat Aparatur Sukamandi akan bervariasi antara skor terendah 22 sampai dengan skor tertinggi 88 .

Berdasarkan data yang diperoleh, skor prestasi kerja pegawai Balai Diklat maksimum, rentang skor, rata-rata, median, modus, standar deviasi, varians skor, dan tabel distribusi frekuensi serta histogram.

Aparatur Sukamandi bervariasi antara skor minimal 54 sampai dengan skor maksimal 84. Pada tahap selanjutnya data dianalisis dengan menggunakan teknik statistik deskriptif. Hasil analisis data memperlihatkan rentang skor variabel prestasi kerja pegawai 30 , rata-rata 72,033 , median 71 modus 71 varians 50,516, dan standar deviasi 7,107. Berdasarkan perbandingan antara skor rata-rata dengan skor teoretik tertinggi diketahui skor prestasi kerja pegawai sebesar $81,86 \%$. Dengan menggunakan jumlah kelas 5 dapat disusun tabel distribusi frekuensi sebagai berikut.

Tabel 1: Distribusi Frekuensi Skor Prestasi Kerja Pegawai

\begin{tabular}{|c|ccc|c|c|c|}
\hline \multirow{2}{*}{ No. } & \multirow{2}{*}{ Kelas Interval } & \multicolumn{4}{|c|}{ Frekuensi } \\
\cline { 4 - 7 } & & \multicolumn{2}{|c|}{ Absolut } & Relatif (\%) & Kumulatif (\%) \\
\hline 1 & 54 & - & 60 & 2 & 6,67 & 6,67 \\
\hline 2 & 61 & - & 67 & 4 & 13,33 & 20,00 \\
\hline 3 & 68 & - & 74 & 14 & 46,67 & 66,67 \\
\hline 4 & 75 & - & 81 & 7 & 23,33 & 90,00 \\
\hline 5 & 82 & 88 & 3 & 10,00 & 100,00 \\
\hline \hline
\end{tabular}

Dalam analisis selanjutnya akan dijelaskan hasil analisis data untuk setiap indikator dalam variabel prestasi kerja pegawai yaitu: (1) bekerja tepat waktu, (2)

\section{Indikator Bekerja Tepat Waktu}

Indikator bekerja tepat waktu diukur menggunakan 4 butir pernyataan. Secara teoretis skor indikator bekerja tepat waktu bervariasi antara 4 sampai 16 . tanggung jawab dalam bekerja, (3) kualitas hasil kerja yang dicapai, (4) ketaatan pada peraturan, serta (5) membina kerjasama.

Berdasarkan data yang diperoleh, skor indikator tersebut bervariasi antara 10 sampai 16 dengan rentang skor 6. Hasil perhitungan diperoleh rata-rata 13,100, 
median 13 modus 12 varians 3,128, dan standar deviasi 1,768. Berdasarkan perbandingan skor rata-rata dengan skor Indikator Tanggung Jawab dalam Bekerja Indikator tanggung jawab dalam bekerja diukur menggunakan 4 butir pernyataan. Secara teoretis skor indikator tanggung jawab dalam bekerja bervariasi antara 4 sampai 16 . Berdasarkan data yang diperoleh, skor indikator tanggung jawab dalam bekerja bervariasi antara 10 sampai Indikator Kualitas Hasil Kerja yang Dicapai Indikator kualitas hasil kerja yang dicapai diukur menggunakan 5 butir pernyataan. Secara teoretis skor indikator kualitas hasil kerja yang dicapai akan bervariasi antara 5 sampai 20. Berdasarkan data yang diperoleh, skor indikator kualitas hasil kerja yang dicapai bervariasi antara 11 sampai 20 dengan rentang skor 9. Hasil

\section{Indikator Ketaatan pada Peraturan}

Indikator ketaatan pada peraturan diukur menggunakan 5 butir pernyataan. Secara teoretis skor indikator ketaatan pada peraturan akan bervariasi antara 5 sampai 20. Berdasarkan data yang diperoleh, skor indikator ketaatan pada peraturan bervariasi antara 11 sampai 20 dengan rentang skor 9.

\section{Indikator Membina Kerjasama}

Indikator membina kerjasama diukur menggunakan 4 butir pernyataan. Secara teoretis skor indikator membina kerjasama akan bervariasi antara 4 sampai 16. Berdasarkan data yang diperoleh, skor indikator membina kerjasama bervariasi antara 9 sampai 16 dengan rentang skor 7 . Hasil perhitungan diperoleh rata-rata 13,033 , median 13, modus 12 , varians teoretik tertinggi, skor indikator bekerja tepat waktu mencapai $81,88 \%$.

16 dengan rentang skor 6. Hasil perhitungan diperoleh rata-rata 13,067, median 13, modus 16, varians 5,099, dan standar deviasi 2,258. Berdasarkan perbandingan skor rata-rata dengan skor teoretik tertinggi, skor indikator tanggung jawab dalam bekerja mencapai $81,67 \%$.

perhitungan diperoleh rata-rata 16,767 , median 17 , modus 16 , varians 4,599 , dan standar deviasi 2,144. Berdasarkan perbandingan skor rata-rata dengan skor teoretik tertinggi, skor indikator kualitas hasil kerja yang dicapai mencapai $83,83 \%$.

Hasil perhitungan diperoleh rata-rata 16,067 , median 16 , modus 16 , varians 5,857 , dan standar deviasi 2,420. Berdasarkan perbandingan skor rata-rata dengan skor teoretik tertinggi, skor indikator ketaatan pada peraturan mencapai $80,33 \%$.

3,895, dan standar deviasi 1,974. Perbandingan skor rata-rata dengan skor teoretik tertinggi menunjukkan skor indikator membina kerjasama mencapai $81,46 \%$.

Berdasarkan deskripsi data setiap indikator dapat dilihat perbandingan presentase skor antar indikator sebagai berikut.

Tabel 2: Presentase Skor Indikator Variabel Prestasi Kerja Pegawai

\begin{tabular}{|c|l|c|}
\hline No. & \multicolumn{1}{|c|}{ Indikator } & Skor $(\boldsymbol{\%})$ \\
\hline 1 & Bekerja tepat waktu & 81,88 \\
\hline 2 & Tanggung jawab dalam bekerja & 81,67 \\
\hline 3 & Kualitas hasil kerja yang dicapai & 83,83 \\
\hline 4 & Ketaatan pada peraturan & 80,33 \\
\hline 5 & Membina kerjasama & 81,46 \\
\hline
\end{tabular}


Tabel di atas menunjukkan indikator kualitas hasil kerja yang dicapai menembpati skor tertinggi yaitu $83,83 \%$ diikuti indikator bekerja tepat waktu yang mencapai skor $81,88 \%$. Indikator ketaatan pada peraturan memiliki skor terendah yaitu

\section{Data Variabel Budaya Organisasi}

Variabel budaya organisasi telah diukur menggunakan kuesioner yang terdiri dari 17 butir pernyataan. Hasil pengukuran untuk setiap butir ditetapkan dengan memberikan bobot skor minimal 1 dan skor maksimal 5 dari setiap alternatif jawaban yang dipilih oleh responden. Dengan demikian, secara teoretis skor variabel budaya organisasi akan bervariasi antara skor terendah 17 sampai dengan skor tertinggi 85 .

Berdasarkan data yang diperoleh, skor budaya organisasi Balai Diklat Aparatur Sukamandi bervariasi antara skor
80,33. Indikator membina kerjasama menempati urutan keempat dengan skor $81,46 \%$. Sedangkan indikator tanggungjawab dalam bekerja di urutan ke ketiga dengan skor $81,67 \%$.

terendah 41 sampai dengan skor tertinggi 68. Pada tahap selanjutnya data dianalisis dengan menggunakan teknik statistik deskriptif. Hasil perhitungan memperlihatkan rentang skor variabel budaya organisasi 27 , rata-rata 53,533, median 52,5 modus 46 varians 79,844 dan standar deviasi 8,963. Berdasarkan perbandingan antara skor rata-rata dengan skor teoretik tertinggi diketahui skor budaya organisasi mencapai 62,98\%. Dengan menggunakan jumlah kelas 5 dapat disusun tabel distribusi frekuensi sebagai berikut.

Tabel 3: Distribusi Frekuensi Skor Budaya organisasi

\begin{tabular}{|c|ccc|c|c|c||}
\hline \multirow{2}{*}{ No. } & \multirow{2}{*}{ Kelas Interval } & \multicolumn{4}{|c||}{ Frekuensi } \\
\cline { 4 - 7 } & \multicolumn{2}{|c|}{ Absolut } & Relatif (\%) & Kumulatif (\%) \\
\hline \hline 1 & 41 & - & 46 & 10 & 33,33 & 33,33 \\
\hline 2 & 47 & - & 52 & 5 & 16,67 & 50,00 \\
\hline 3 & 53 & - & 58 & 4 & 13,33 & 63,33 \\
\hline 4 & 59 & - & 64 & 6 & 20,00 & 83,33 \\
\hline 5 & 65 & - & 70 & 5 & 16,67 & 100,00 \\
\hline
\end{tabular}

Selanjutnya dijelaskan hasil analisis data untuk setiap indikator dalam variabel budaya organisasi meliputi: (1) struktur

\section{Indikator Struktur Tugas}

Indikator diukur menggunakan 4 butir pernyataan. Secara teoretis skor indikator inisiatif individu akan bervariasi antara 4 sampai 20 . Berdasarkan data yang tugas, (2) peraturan yang berlaku, (3) interaksi antar pegawai, dan (4) penghargaan terhadap prestasi

diperoleh, skor indikator struktur tugas bervariasi antara 9 sampai 18 dengan rentang skor 9. Hasil perhitungan diperoleh rata-rata 13,100 , median 13 modus 12 
varians 6,162, dan standar deviasi 2,482. Berdasarkan perbandingan skor rata-rata

\section{Indikator Peraturan yang Berlaku}

Indikator peraturan yang berlaku diukur menggunakan 5 butir pernyataan. Secara teoretis skor indikator peraturan yang berlaku akan bervariasi antara 5 sampai 25. Berdasarkan data yang diperoleh, skor indikator peraturan yang berlaku bervariasi antara 10 sampai 22

\section{Indikator Interaksi antar Pegawai}

Indikator interaksi antar pegawai diukur menggunakan 4 butir pernyataan. Secara teoretis skor indikator interaksi antar pegawai akan bervariasi antara 4 sampai 20. Berdasarkan data yang diperoleh, skor indikator interaksi antar pegawai bervariasi antara 8 sampai 16 dengan rentang skor 8 .

\section{Indikator Penghargaan terhadap Prestasi}

Indikator penghargaan terhadap prestasi diukur menggunakan 4 butir pernyataan. Secara teoretis skor indikator penghargaan terhadap prestasi akan bervariasi antara 4 sampai 20. Berdasarkan data yang diperoleh, skor indikator penghargaan terhadap prestasi bervariasi antara 8 sampai 17 dengan rentang skor 9 . Hasil perhitungan diperoleh rata-rata indikator penghargaan terhadap prestasi 12,300, median 13 modus 14 varians 4,907, dengan skor teoretik tertinggi, skor indikator struktur tugas mencapai $60,50 \%$.

dengan rentang skor 12 . Hasil perhitungan diperoleh rata-rata 15,533 , median 16 modus 12 varians 12,671, dan standar deviasi 3,560. Berdasarkan perbandingan skor rata-rata dengan skor teoretik tertinggi, skor indikator peraturan yang berlaku mencapai $62,13 \%$.

Hasil perhitungan diperoleh rata-rata 12,600 , median 12,5 modus 11 varians 5,490 , dan standar deviasi 2,343. Berdasarkan perbandingan skor rata-rata dengan skor teoretik tertinggi, skor indikator interaksi antar pegawai mencapai $63,00 \%$.

dan standar deviasi 2,215. Berdasarkan perbandingan skor rata-rata dengan skor teoretik tertinggi, skor indikator penghargaan terhadap prestasi mencapai $61,50 \%$.

Berdasarkan deskripsi data setiap indikator dapat dilihat perbandingan presentase skor antar indikator yang terdapat dalam variabel budaya organisasi diperlihatkan dalam tabel berikut.

Tabel 4: Presentase Skor Indikator Variabel

Budaya Organisasi

\begin{tabular}{|c|l|c|}
\hline No. & \multicolumn{1}{|c|}{ Indikator } & Skor (\%) \\
\hline \hline 1 & Struktur tugas & 65,50 \\
\hline 2 & Peraturan yang berlaku & 62,13 \\
\hline 3 & Interaksi antar pegawai & 63,00 \\
\hline 4 & Penghargaan terhadap prestasi & 61,50 \\
\hline
\end{tabular}

Berdasarkan tabel di atas, indikator struktur menempati skor tertinggi yaitu $65,50 \%$ kemudian diikuti oleh indikator interaksi antar pegawai yang mencapai skor $63,00 \%$. Indikator penghargaan terhadap prestasi menempati urutan paling rendah yaitu $61,50 \%$. Sedangkan indikator peraturan yang berlaku berada di urutan ke ketiga dengan skor $62,13 \%$. 


\section{Prestasi Kerja Pegawai dan Budaya Organisasi}

Melalui penelitian dikaji variabel budaya organisasi dan prestasi keterkaitan antara variabel budaya kerja pegawai. Tabel berikut menunjukkan organisasi dan prestasi kerja pegawai. perbandingan presentase skor rata-rata Untuk melihat kerkaitan tersebut berikut ini antara kedua variabel serta antar indikator diperlihatkan perbandingan data skor dalam variabel dimaksud.

Tabel 5: Perbandingan Presentase Skor Budaya Organisasi dan Prestasi kerja pegawai

\begin{tabular}{|c|c|c|c|c|}
\hline \multirow{2}{*}{ No. } & \multirow{2}{*}{ Variabel } & \multirow{2}{*}{ Indikator } & \multicolumn{2}{|c|}{ Skor $(\%)$} \\
\hline & & & Indikator & Variabel \\
\hline \multirow{5}{*}{1} & \multirow{5}{*}{$\begin{array}{l}\text { Prestasi kerja } \\
\text { pegawai }\end{array}$} & Bekerja tepat waktu & 81,88 & \multirow{5}{*}{81,66} \\
\hline & & Tanggung jawab dalam bekerja & 81,67 & \\
\hline & & Kualitas hasil kerja yang dicapai & 83,83 & \\
\hline & & Ketaatan pada peraturan & 80,33 & \\
\hline & & Membina kerjasama & 81,46 & \\
\hline \multirow{4}{*}{2} & \multirow{4}{*}{$\begin{array}{l}\text { Budaya } \\
\text { Organisasi }\end{array}$} & Struktur tugas & 65,50 & \multirow{4}{*}{62,98} \\
\hline & & Peraturan yang berlaku & 62,13 & \\
\hline & & Interaksi antar pegawai & 63,00 & \\
\hline & & Penghargaan terhadap prestasi & 61,50 & \\
\hline
\end{tabular}

Tabel di atas memperlihatkan bahwa skor variabel prestasi kerja pegawai mencapai $81,66 \%$, sedangkan skor variabel budaya organisasi mencapai $62,98 \%$.

Untuk memberikan deskripsi yang lebih jelas, selanjutnya dapat dilihat

\section{HASIL PENELITIAN}

\section{Prestasi Kerja Pegawai}

Pada umumnya makna prestasi kerja pegawai diberi batasan sebagai kesuksesan seorang pegawai dalam melaksanakan suatu pekerjaan. Prestasi kerja dianggap sebagai tingkat keberhasilan dalam mencapai tujuan pekerjaan yang telah ditetapkan. Dengan kata lain, prestasi kerja dapat dinyatakan sebagai wujud kemampuan seseorang dalam melaksanakan perbandingan skor antar indikator dari masing-masing variabel. Dalam hal ini terdapat lima indikator untuk variabel prestasi kerja pegawai serta terdapat empat indikator variabel budaya organisasi.

suatu pekerjaan sesuai dengan tujuan atau standar yang telah ditetapkan baik itu standar proses maupun standar hasil.

Melalui pengukuran yang telah dilakukan dalam penelitian ini diperoleh temuan bahwa prestasi kerja pegawai di Balai Diklat Aparatur Sukamandi mencapai tingkatan 81,86\%. Angka tersebut menunjukkan bahwa prestasi kerja pegawai 
sudah cukup baik. Berdasarkan indikator pengukuran yang digunakan, prestasi kerja pegawai paling tinggi ditunjukkan oleh indikator kualitas hasil kerja yang dicapai. Sedangkan untuk ketaatan pada peraturan relatif lebih rendah.

Prestasi kerja adalah hasil kerja yang dicapai seorang pegawai dalam melaksanakan tugas-tugas yang dibebankan kepadanya yang didasarkan atas kecakapan, pengalaman dan kesungguhan serta waktu. Kualitas hasil kerja yang dicapai merujuk pada mutu serta ketepatan pegawai dalam melaksanakan pekerjaan yang dibebankan kepadanya. Aspek penting dari kualitas kerja yang telah diungkap melalui penelitian ini produk yang dihasilkan sehingga dapat dijadikan contoh oleh rekan kerja atau mendapat pengakuan dari atasan yang menilai kinerja. Untuk mencapai kualitas hasil tersebut pelaksanaan pekerjaan harus terhindar dari kekeliruan serta selesai lebih cepat dari jadwal yang telah ditetapkan. Dalam prkateknya, hasil kerja yang berkualitas dapat dicapai dengan menggunakan cara-cara inovatif dalam melaksanakan pekerjaan.

Tanggung jawab dalam bekerja bukan hanya menyelesaikan sejumlah tugas yang diberikan kepada, tetapi ada evaluasi terhadap kerjatersebut. Bekerja yang bertanggung jawab adalah bekerja dengan penuh kesadaran sehingga untuk memulai pekerjaan tidak harus menunggu perintah dati atasan. Di samping itu, tanggung jawab dalam bekerja dapat ditunjukkan oleh keinginan untuk memperbaiki kesalahan serta melaksanakan tugas sampai tuntas bahkan bersedia mengorbankan waktu dan tenaga. Rasa tanggung jawab yang besar sangat dominan pengaruhnya dalam kualitas kerja. Walaupun pekerjaan yang harus diselesaikan banyak, semangat untuk segera menyelesaikannya tetap tinggi.

Setiap pegawai diharapkan bekerja tepat waktu yang mengarah pada efisiensi kerja. Semakin singkat waktu yang diperlukan untuk menyelesaikan suatu pekerjaan, maka semakin besar andil pegawai dalam menciptakan efisiensi organisasi. Hal ini terkait dengan ritme kerja dalam arti tidak menunda-nunda sehingga akan lebih mampu menghasilkan kinerja optimal. Bekerja tepat waktu, berarti menghargai deadline. Akibat yang ditimbulkan bila melanggar deadline bisa bermacam-macam, dari tumpukan pekerjaan, sampai kinerja terganggu. Suatu kebanggaan bila seorang pegawai dapat mengerjakan tugas tepat pada waktunya.

Di dalam bekerja, ada banyak perilaku (sebagian tepat, sebagian tidak) yang dapat dilakukan oleh seorang karyawan. Arah perilaku mengacu pada perilaku yang dipilih oleh seseorang di dalam bekerja dari banyak pilihan perilaku yang dapat mereka jalankan baik tepat maupun tidak. Banyak contoh perilaku tidak tepat yang dapat dilakukan oleh seorang karyawan, perilaku-perilaku ini nantinya akan menjadi suatu penghambat bagi organisasi di dalam mencapai tujuannya. Untuk mencapai tujuan pekerjaan secara maksimal, karyawan harus memiliki perilaku yang fungsional dan dapat membantu organisasi dalam mencapai tujuannya. Wujud dari perilaku ini adalah ketaan pada peraturan yang ditetapkan oleh organisasi.

Aspek penting lain dari prestasi kerja pegawai adalah mampu mebina kerjasama sesama rekan kerja. Kerja sama mempunyai beberapa manfaat mendorong terciptanya sinergi serta terciptanya hubungan yang harmonis antar pegawai. Kerja sama yang dibina dengan baik akan menciptakan praktek kerja yang sehat serta meningkatkan semangat kelompok dan meningkatkan kualitas proses dan hasil kerja. Bentuk nyata kerjasama sebagai wujud prestasi kerja pegawai antara lain membantu rekan kerja yang mengalami kesulitan dalam melaksanakan tugas, terlibat dalam penyelesaian konflik yang terjadi antar rekan kerja, serta memberikan dukungan pada rekan kerja dalam menyelesaikan suatu pekerjaan. 


\section{Budaya Organisasi}

Budaya organisasi merupakan persepsi umum yang dipegang teguh oleh para anggota organisasi dan menjadi sebuah sistem yang mengandung kesamaan pengertian. Budaya organisasi dapat dipandang sebagai suatu karakteristik organisasi yang berkembang dalam sebuah organisasi tertentu serta dijadikan acuan oleh setiap anggota organisasi. Budaya yang kuat memperlihatkan kesepakatan yang tinggi dikalangan anggota mengenai apa yang harus dilakukan dalam organisasi tersebut. Kekuatan budaya organisasi semacam itu akan membina komitmen terhadap organisasi serta perilaku anggota organisasi.

Melalui pengukuran yang telah dilakukan dalam penelitian ini diperoleh temuan bahwa budaya organisasi Balai Diklat Aparatur Sukamandi mencapai tingkatan $62,98 \%$. Hal ini menunjukkan masih lemhnya budaya organisasi dalam mengarahkan perilaku pegawai. Berdasarkan indikator yang digunakan dalam pengukurannya, indikator budaya organisasi tertinggi adalah struktur tugas. Sedangkan untuk indikator penghargaan terhadap prestasi relatif relatif lebih rendah dibandingkan dengan yang lainnya.

Dengan ditetapkan struktur tugas akan membuat suatu organisasi lebih efektif. Tujuan yang jelas membuat organisasi, pimpinan dan karyawan melaksanakan tugas lebih efektif dan efisien. Struktur tugas menjelaskan sampai sejauh mana tugas-tugas dalam organisasi didefinisikan secara jelas dan sampai sejauh mana definisi tugas-tugas tersebut dilengkapi dengan petunjuk yang rinci dan prosedur yang baku. Struktur tugas mencakup perincian metode yang dipakai oleh pegawai untuk melaksanakan tugas yang dibebankan oleh organisasi. Struktur tugas menunjuk pada bagaimana pembagian tugas dan wewenang itu dilaksanakan. Sehingga ada kejelasan tentang 'siapa bertanggung jawab apa' serta keberadaan mekanisme pelaksanaan tugas dalam hal "siapa bertanggung jawab kepada siapa. Struktur tugas harus jelas, dan mekanisme harus dijalankan. Jika tidak, bukan tidak mungkin seorang karyawan tidak dapat bekerja, jika mereka tidak tahu harus mengerjakan apa. Atau banyak orang yang mengendalikan atau memberi perintah langsung pada seorang karyawan, sehingga pegawai tidak tahu tugas mana yang harus diselesaikan. Untuk itu, menjadi kewajiban manajemen untuk menjamin, bahwa struktur tugas bagi setiap pegawai harus jelas, beserta mekanisme dan herarki pelaksanaan tugas dipatuhi.

Budaya organisasi akan mengajarkan anggotangan memperjuangkan apa yang diinginkan oleh organisasi. Budaya organisasi melihat bahwa hal terpenting dan ukuran keberhasilan ditentukan oleh kemampuan mematuhi aturan yang berlaku, kondisi ini tentunya menjadikan peraturan yang seharusnya merupakan "alat" berubah menjadi tujuan itu sendiri. Budaya organisasi merupakan aspek penting yang menentukan sikap kerja seorang pegawai baik itu kinerja, kepuasan kerja, maupun tingkat kemangkirannya. Salah satu aspek yang bisa diper gunakan untuk melihat budaya kerja pegawai adalah disiplin kerja.Disiplin kerja merupakan ketaatan pada peraturan yang berlaku di dalam proses pelaksanaan pekerjaan.

$$
\text { Budaya organisasi akan }
$$

memberikan warna bagaimana interaksi antar pegawai. Tanpa interaksi antarpegawai di dalamnya, mustahil sebuah institusi bisa bergerak dan maju. Dalam hal interaksi di kantor, setiap pegawai pasti bertemu dan berhadapan dengan pegawai lain dengan bermacam karakter atau tabiat yang tentu berbeda-beda pula. Dan untuk menghadapinya, tentu dibutuhkan kesepahaman yang telah menjadi budaya organisasi. Keakraban dan persahabatan antara pegawai merupakan bentuk budaya organisasi. Setiap organisasi harus bekerja dengan aturan main tentang hubungan antar rekan kerja dengan cara keterbukaan dan keakraban dalam konteks pengaturan tugastugas organisasi.

Penghargaan terhadap prestasi merupakan indikator yang dapat diukur dari budaya organisasi. Penilaian hasil kerja berdasarkan kriteria yang jelas (kenaikan gaji, promosi) adalah unsur penting yang menjadi bagian dari budaya organisasi. 
Kejelasan kriteria ini akan membuat karyawan puas sehingga akan memberikan dalam terhadap perilaku dalam melaksanakan pekerjaan. Penghargaan yang sesuai harapan pegawai dengan mekanisme dan prosedur pemberian yang efektif, dapat berfungsi untuk meningkatkan motivasi pegawai secara individu. Hal ini akan mendorong pegawai mempunyai keinginan yang kuat untuk berusaha mencapai targettarget pekerjaan secara efektif.

\section{Budaya Organisasi dalam Peningkatan Prestasi kerja pegawai}

Prestasi kerja merupakan faktor utama yang dituntut oleh setiap organisasi/perusahaan. Tercapainya peningkatan prestasi kerja pegawai tidak lepas dari budaya organisasi yang ada di suatu organisasi. Budaya organisasi yang positif akan memberikan pengaruh positif kepada pegawai sehingga mampu mengembangkan oraganisasi ke arah yang lebih baik. Budaya organisasi merupakan nilai yang menjadi pedoman sumber daya manusia untuk menghadapi permasalahan baik eksternal maupun internal dan usaha penyesuaian integrasi ke dalam perusahaan sehingga masing-masing anggota organisasi harus memahami nilai-nilai yang ada, bagaimana harus bertindak dan berperilaku. Hal ini sejalan dengan pengertian budaya organisasi yang dikemukakan oleh Schein: "A pattern of share basic assumption that the group learner as it solved its problems of external adaptation anda internal integration, that has worked well enough to be considered valid and therefore, to be taught to new members as the correct way to perceive, think and feel in relation to these problems". ${ }^{1}$

Pengaruh budaya pada perilaku individu tergambar dalam fungsi-fungsi budaya yang kemukakan Robbins yaitu budaya sebagai mekanisme pembuat makna dan kendali yang memandu sikap dan perilaku anggota organisasi. ${ }^{2}$ Dengan demikian budaya organisasi dapat menjadikan anggota organisasi untuk lebih fokus pada pencapaian tujuan organisasi melalui tugas-tugas yang diberikan kepadanya.
Budaya organisasi dan prestasi kerja pegawai terkait antara satu dengan yang lain. Budaya organisasi sebagai nilainilai organisasi akan dijadikan sebagai pedoman pegawai berperilaku dalam menyelesaikan tugasnya. Dengan budaya organisasi yang baik, maka pegawai akan berperilaku baik. Kondisi ini akan meningkatkan prestasi kerja pegawai yang selanjutnya akan meningkatkan kinerja oragnisasi secara keseluruhan.

Adanya keterkaitan hubungan antara budaya organisasi dengan prestasi kerja pegawai yang dapat dijelaskan dalam model diagnosis bahwa semakin baik kualitas faktor-faktor yang terdapat dalam budaya organisasi makin baik kinerja pegawai. Pegawai yang sudah memahami keseluruhan nilai-nilai organisasi akan menjadikan nilai-nilai tersebut sebagai suatu kepribadian organisasi. Nilai dan keyakinan tersebut akan diwujudkan menjadi perilaku keseharian mereka dalam bekerja, sehingga akan menjadi kinerja individual.

Temuan berbagai penelitian menunjukkan bahwa terdapat korelasi positif dan signifikan antara budaya organisasi dengan prestasi kerja pagawai. Atas dasar itu, pengembangan budaya organisasi menjadi trend di lingkungan organisasi saat ini, hal ini tampak dari banyaknya program-program pengembangan budaya organisasi. Dengan implementasi budaya kerja diharapkan akan berpengaruh positif terhadap peningkatan prestasi kerja pegawai, khususnya di Balai Diklat Aparatur Sukamandi. 


\section{PENUTUP}

\section{Kesimpulan}

Berdasarkan hasil penelitian yang dikemukakan dalam pembahasan sebelumnya diperoleh kesimpulan sebagai berikut:

1. Prestasi kerja pegawai di Balai Diklat Aparatur Sukamandi relatif baik mencapai tingkat $81,86 \%$. Hal ini ditunjukkan oleh penampilan pegawai dalam melaksanakan pekerjaan secara tepat waktu, memiliki tanggung jawab dalam bekerja, memperlihatkan kualitas hasil kerja yang dicapai, mentaati pada peraturan, dan membina kerjasama.

1. Budaya organisasi di Balai Diklat Aparatur Sukamandi relatif rendah hanya mencapai tingkatan $62,98 \%$. Hal ini ditunjukkan oleh nilai-nilai dan norma tentang struktur tugas,

\section{Saran}

Melalui penelitian ini diketahui adanya karakteristik budaya organisasi yang dapat mendungkung peningkatan prestasi kerja pegawai. Terkait dengan hal tersebut dapat dikemukakan saran-saran untuk memperkuat budaya organisasi dalam meningkatkan kinerja.

\section{Saran untuk Pegawai}

Pegawai pada hakekatnya adalah anggota organisasi yang memiliki turut menguatkan budaya untuk meningkatkan kinerja organisasi. Adanya kesepahaman di antara pegawai tentang nilai-nilai budaya akan menyatukan perilaku dalam melakukan pekerjaan. Mampu tidaknya seorang pegawai menampilkan prestasi kerja tidak terlepas komitmen terhadap organisasi dan tugas yang menjadi tanggungjawabnya. Hal ini menekankan perlunya setiap pegawai memiliki pemahaman tentang budaya organisasi sehingga tahu kemana arah yang dituju organisasi tempatnya bekerja.

Langkah-langkah yang perlu dilakukan pegawai dalam memahami karakteristik budaya organisasi adalah: (1) Mempelajari kebijakan dan peraturan (tatatertib) yang berlaku di lingkungan peraturan yang berlaku, interaksi antar pegawai, dan penghargaan terhadap prestasi yang belum disepakati secara utuh sebagai acuan dalam melaksanakan aktivitas untuk mencapai tujuan organisasi sehingga masih harus ditingkatkan.

2. Budaya organisasi berpotensi mengarahkan pegawai dalam meningkatkan prestasi kerja. Kesepakatan terhadap nilai-nilai dan norma organisasi akan mendorong pegawai dalam melaksanakan pekerjaan sesuai dengan tujuan organisasi. Hal ini ditunjukan terutama oleh struktur tugas yang dapat mengarahkan pegawai menunjukkan kualitas hasil kerja.

organisasi; (2) Mengamati pola perilaku pegawai lain dalam melakukan aktivitas kerjanya sehari-hari; (3) Meningkatkan interaksi komunikasi baik secara vertikal ataupun secara horisontal; serta (4) Mendiskusikan upaya pemecahan masalah yang dihadapi baik itu dengan rekan kerja atau dengan atasan.

\section{Saran untuk Manajer/Pimpinan Lembaga \\ Kedudukan manajemen dan} pemimpin dalam organisasi perlu menjadi bahan refleksi bersama agar peran pemimpin diterima dan dihayati oleh para anggotanya dalam internalisasi budaya serta berbagai nilai kebersamaan. Bagian terpenting dari tugas seorang manajer/pemimpin adalah bertanggung jawab dalam pembentukan dan pengembangan budaya organisasi melalui identifikasi nilai-nilai dan prinsip dasar organisasi, memberikan contoh dari nilainilai tersebut pada pegawai, memahami karakteristik budaya organisasi secara utuh baik segi positif dan negatifnya dan memperkuat nilai-nilai yang dapat menunjang peningkatan prestasi kerja 
pegawai .

Tindakan pimpinan dalam pengembangan budaya organisasi untuk meningkatkan kinerja antara lain menetapkan dan mengkomunikasikan

\section{DAFTAR PUSTAKA}

Bacal, Robert Performance Management alih bahasa: Surya Dharma dan Yanuar Irawan. Jakarta: Gramedia, 2002.

Bernardin, John H. and E. A. Russel, Human Resources Management, an Experiental Approach. Singapore: $\quad$ McGraww-Hill, 1993.

Gibson, James L., John M. Ivancevich and James H. Donnelly, Organisasi: Perilaku, Struktur, Proses, alih bahasa Nunuk Adiarni. Jakarta: Binarupa Aksara, 1996.

Gray, Edmund R. and Larry R.Smeltzer, Management : The Competitius Edge,. Singapore: Macmillan, 1990.

Kast, Fremont E. dan James E. Roseinzweig, Organization and Management, Terjemahan Hasmy Ali. Jakarta : PT. Bumi Aksara, 1985.

Kirkpatrick, Thomas O. and Chad T. Lewis, Effective Supervisor : Preparing for 21 Century . Orlando : The Dryden Press, 1995.

Kolb, David A., Joyce S. Osland, and Irwin M. Rubin, The Organizational Behavior Reader,. New Jersey : Englewood Cliff Prentice Hall, 1995.

Kotter, John P. and James L. Hasket, Corporate Culture and Performance. New York: The Free Press A Division of McMillan Inc., 1992. p 3

Mangkunegara, A. Anwar Prabu. Manajemen Sumber Daya Manusia Perusahaan. Bandung: Remaja Rosdakarya, 2000.

McNamara, Carter. Organizational Culture : Applies to nonprofits struktur tugas secara jelas, konsisten dalam menegakan peraturan, memfasilitasi interaksi anta pegawai serta memberikan penghargaan pada pegawai berdasarkan kemampuan dan prestasinya.

and for Profits Unless Noted,. http://www-

mapnp.org.thry/culture/culture.h tm, 2000.

Mondy, R. Wayne and Robert M. Noe, Human Resources Management. Massachusetts: Allyn \& Bacon, 1990.

Muhammad, Armi. Komunikasi Organisasi, . Jakarta : Rineka Cipta, 2000.

Nawawi, Hadari. Manajemen Sumber Daya Manusia untuk Bisnis yang Kompetitif, . Yogyakarta : Gajahmada University Press, 2000.

Ndraha, Talizuhu Budaya Organisasi. Jakarta : Rineka Cipta,1997.

Prawirasentono, Suryadi Manajemen Sumber Daya Manusia: Kebijakan Prestasi kerja Karyawan. Yogyakarta : BPFE, 1999 .

Robbins, Stephen P. Perilaku Organisasi,. Jakarta : PT. Prenhallindo, 1996.

. Teori Organisasi, Struktur,

Desain dan Aplikasi,

Terjemahan Jusuf Udaya. Jakarta : Arcan, 1990.

Robbins, Stephen P. and Mary Coulter, Manajemen, Terjemahan $\mathrm{T}$. Hermaya. Jakarta : PT. Prenhallindo, 1999.

Schein, Edgar H. Organizational Culture and Leadership (San Fransisco: Josse Bass Inc., 1985.

Sedarmayanti. Sumberdaya Manusia dan Produktivitas Kerja. Bandung: Mandar Maju, 2001.

Simamora, Hendri. Manajemen Sumber Daya Manusia. Yogyakarta: Sekolah Tinggi Ilmu Ekonomi YKPN, 1995. 
Siswanto, Bejo, Dasar-dasar Manajemen. Jakarta: Penerbit Ghalia Indonesia, 1999.

Spencer, Lyle $M$. and Signe $M$. Spencer, Competence Work: Models for Superior Performance. NewYork: John Wiley and Sons, 1993.

Sudarno, Indriyo Gito Perilaku Keorganisasian,. Yogyakarya : BPFE, 2000.

Timpe, Dale ed. Seri Ilmu dan Seri Manajemen Bisnis: Kinerja. Jakarta: Gramedia, 1993.

Whitmore, John. Coaching for Performance; Seni Mengarahkan untuk Mendongkrak Kinerja, terjemahan Y. D. Helly Purnomo. Jakarta: Gramedia, 1997. 